\title{
THE VARIABILITY OF MORUS ALBA L. (MORACEAE) LEAVES IN THE GREEN AREAS OF POZNAŃ
}

\author{
Marta Kachel, Renata NowińsKa, Mągorzata Klimko
}

\begin{abstract}
M. Kachel, R. Nowińska, M. Klimko, Department of Botany, Poznań University of Life Sciences, Wojska Polskiego 71 C, 60-625 Poznań, Poland. e-mail: martakachel5@gmail.com; renata.nowinska@up.poznan. pl; malgorzata.klimko@up.poznan.pl
\end{abstract}

(Received: July 18, 2016. Accepted: January 17, 2017)

\begin{abstract}
The paper presents the results of a biometrical study on the leaves of vegetative and generative shoots of Morus alba. Mature leaves were collected from the green areas of Poznań (Poland) city. Leaves from vegetative shoots were collected from 34 sites. Leaves from generative shoots were collected from specimens with blackish purple or purple fruit (13 trees) and with pale yellow to creamy fruit (21 trees). Eleven morphological traits were analysed in the leaves from vegetative and generative shoots, including the petiole and blade. The seven examined features were characterised by low or moderate variability and four features were characterised by high or very high variability. The research revealed slight differences between trees with blackish purple or pale yellow fruit and significant morphological differences between the leaves of vegetative and generative shoots. The article includes descriptions of quantitative features have not been published in Poland. White mulberry leaves (Morus alba) with white and dark fruit did not make clearly separated groups. Therefore, they should be treated as morphotype of cultivars rather than a distinct taxonomic rank.
\end{abstract}

KEY WORDS: white mulberry, morphology, petiole, blade, fruit, taxonomic, Poland

\section{INTRODUCTION}

The mulberry family comprises about 50 genera of trees, shrubs, climbers and herbaceous plants, often with milky sap. 12-16 species were distinguished within the Morus genus (Bugata 2000, ZHEKUn \& GILBERT 2003) which can be found both in the tropical and temperate zone. Mulberries naturally grow in forests in the mountains of Japan, China and India (Bugata 2000, Zhekun \& Gilbert 2003, Seneta \& DOLATOWSKI 2011).

Identification of the Morus genus is based on the morphological traits of leaves and fruit. The leaves are usually single, undivided or palmate lobed, margin toothed; primary veins 3-5 from base, secondary veins pinnate. Fruit with enlarged, succulent calyx usually aggregated into juicy syncarp. The leaves are used as food for silkworms and the fruit for human consumption (ZheKun \& GilberT 2003). The high diversity of leaves of cultivated and naturally growing Morus sp. depends on the cultivation, use, the age of a tree and the environmental conditions (GOLAŃSKI
1957, Peris et al. 2014). ToKARsKa-GuZIK et al. (2012) consider white mulberry to be a domesticated species in Poland. It is often used in urban and rural green spaces because it can be grown easily. It is dispersed in western and central Poland. Some white mulberry trees are older than 100 years, which shows that the species has adapted to the existing conditions (РокоRNÝ 1992). Morus alba with some other species, like Pyrus communis L., Sophora japonica L., Quercus petrea L., Q. robur L., Eleagnus angustifolia L. belong to the group of plants most resistant to unfavourable conditions (ŁUKASIEWICZ 2011). Biometrical data referring to M. alba variability are usually limited to the extreme lamina length and width and less frequently to the petiole length (KREMer 1995, ZheKun \& GiLBERT 2003, Peris et al. 2014). So far there has been no research on the morphological variability of $M$. alba leaves in Poland. The study by Kuimko (2016) concerned the micromorphology and anatomy of leaves.

The main goal of this study was to determine the morphological variability of $M$. alba leaves from specimens cultivated as ornamental plants in temperate 
regions. The differentiation of leaves was described in reference to its placement on shoots (leaves collected from fertile short shoots and sterile long shoots) as well as in reference to fruits' color variability (trees with white and dark fruits).

\section{MATERIAL AND METHODS}

Fully developed M. alba leaves were collected from unpruned trees aged 35 to 40 years growing in the green areas of Poznań (Poland) (Table 1). Material was collected at 34 sites of street, residential areas and parks. Leaves were collected from trees with different colours of fruit: dark purple or purple fruit (13 trees; hereinafter referred to as dark fruit) and light yellow or creamy fruit (21 trees; hereinafter referred to as white fruit). Five vegetative and five generative shoots were randomly collected from each tree in the middle part of the crown and 10 leaves were measured from each shoot. The studied characteris- tics and methods of measuring are shown in Table 2 and Figure 1. These measurements have been adopted from Staszkiewicz (1997), Adolkar et al. (2007) and Food and Agriculture Organization (FAO/IAEA 2007). The range (minimum-maximum), arithmetic mean $(\mathrm{X})$ and coefficient of variation $(\mathrm{CV})$ were calculated for each of the studied trait (Tables 3, 4). Student's t-test for dependent samples was used to test the significance of differences between the traits in leaves collected from vegetative and generative shoots. The blade length/width correlation and the blade length/petiole length correlation were calculated separately for the leaves from vegetative and generative shoots. The following classes of the correlation strength were identified: $0.0 \leq \mathrm{r} \leq 0.2-$ no correlation; $0.2<\mathrm{r} \leq 0.4$ - weak correlation; $0.4<\mathrm{r}$ $\leq 0.7$ - moderate correlation; $0.7<\mathrm{r} \leq 0.9$ - strong correlation; $0.9<\mathrm{r} \leq 1.0$ - very strong correlation. The chi-square test was used to compare the strength of correlations in the leaves from the two types of

Table 1. A list of tree locations

\begin{tabular}{lccc}
\hline \multicolumn{1}{c}{ Locality } & No. of tree & Date of collection & Fruit color \\
\hline Lazurowa & 1 & 27.07 .2015 & white \\
Dąbrowskiego & $2-5$ & 27.07 .2015 & dark \\
Szydłowska & 6 & 27.07 .2015 & dark \\
Łęgi Dębińskie & 7 & 20.07 .2015 & dark \\
Malta (Baraniaka) & 8,9 & 04.07 .2015 & white \\
Rubież & 10 & 11.07 .2015 & dark \\
Dziadoszańska & 11 & 08.07 .2015 & white \\
Park Tysiąclecia & $12-14$ & 20.07 .2015 & white \\
Warszawska & 15 & 20.07 .2015 & white \\
Malta (Komandoria) & 16 & 20.07 .2015 & dark \\
Szelągowska & 17,18 & 12.07 .2015 & white \\
Czarnucha & 19 & 12.07 .2015 & dark \\
Włodarska & 20 & 12.07 .2015 & white \\
Pasterska/Żytnia & 21 & 12.07 .2015 & white \\
Żytnia/Karbowska & 22 & 12.07 .2015 & white \\
Osiedle Lecha & $23-29$ & 14.07 .2015 & white \\
Osiedle Lecha & 24 & 14.07 .2015 & dark \\
Park Cytadela & 30,31 & 30.08 .2015 & dark \\
Park Cytadela & 32,33 & 30.08 .2015 & 18.07 .2015 \\
Park Cytadela & 34 & & white \\
\hline
\end{tabular}

Table 2. Quantitative characters studied in Morus alba

\begin{tabular}{rcl}
\hline No. & Abbreviation & Character \\
\hline 1 & PL & length of petiole $(\mathrm{cm})$ \\
2 & BL & length of the blade $(\mathrm{cm})$ \\
3 & BW & width of the blade $(\mathrm{cm})$ \\
4 & BL/BW & ratio between length and width of the blade \\
5 & PWB & position of the widest part of a blade as percentage of its length \\
6 & NVL & number of veins to the left of the midrib \\
7 & NVR & number of veins to the right of the midrib \\
8 & DLL & depth of incision in the lower lobe $(\mathrm{cm})$ \\
9 & DB & depth of incision in the blade $(\mathrm{cm})$ \\
10 & LL & length of lateral lobe $(\mathrm{cm})$ \\
11 & NL & number of lobes \\
\hline
\end{tabular}



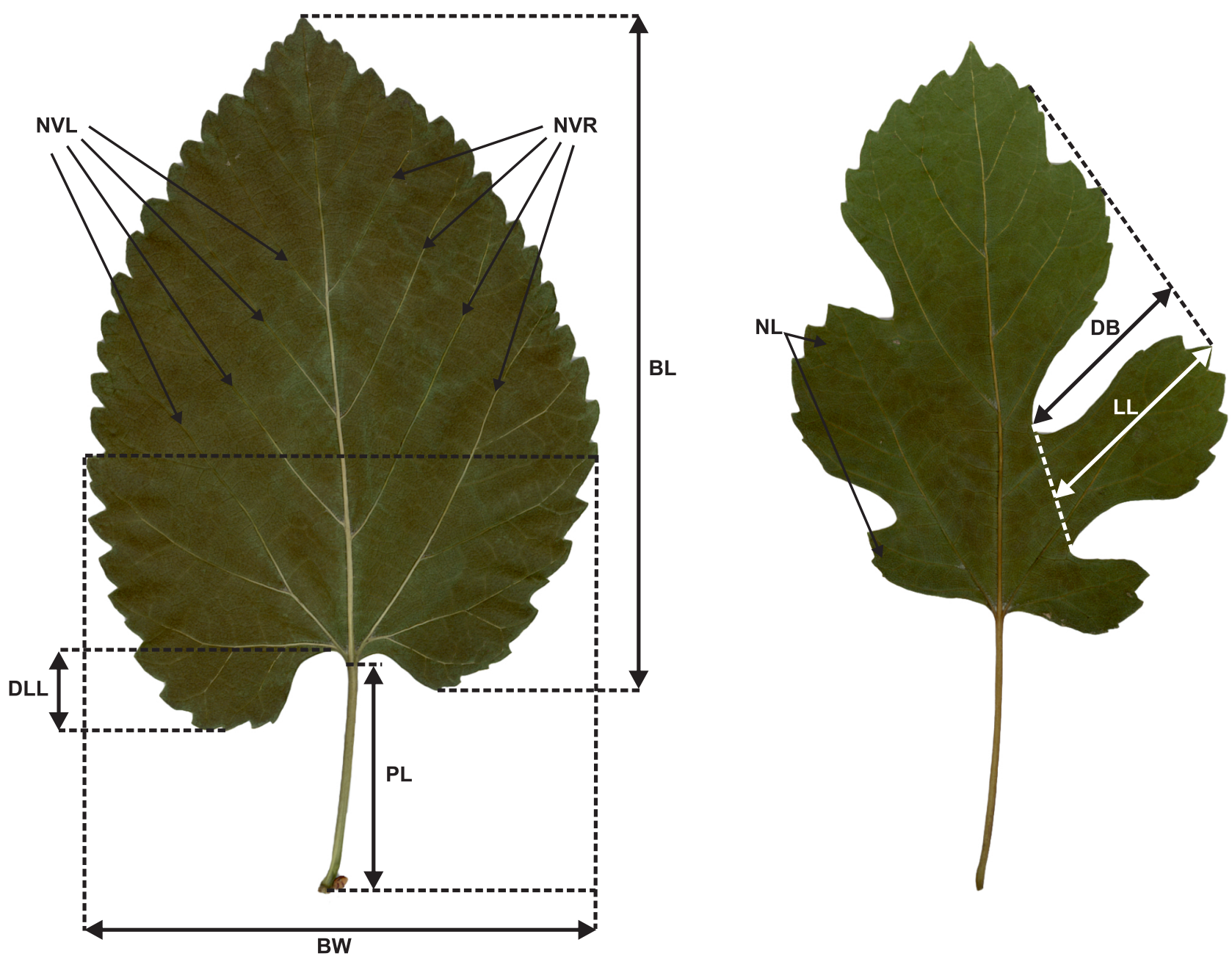

Fig. 1. Morus alba leaf measurement method (characters as in Table 2)

shoots. The differences among analysed individuals were verified by the cluster analysis using the nearest neighbour method and Euclidean distances (WATAEA 2002). The principal component analysis (PCA) and scatter diagram were made was performed to check the discontinuity between the leaves from trees of different colors of fruits (SOKAL \& SNEATH 1973). The data were analysed statistically by Statistica 11 PL for Windows.

\section{RESULTS}

The ranges and variability of the examined features of leaves from generative and vegetative shoots are present in Figures 2 and 3. The mean petiole length (PL) varied from 1.65 to $6.96 \mathrm{~cm}$, on vegetative shoots and from 1.44 to $4.02 \mathrm{~cm}$ on generative ones. The coefficients of variation on vegetative and generative shoots ranged from low to moderate (Tables 3 , 4). The mean of blade length (BL) varied from 5.97 to $12.84 \mathrm{~cm}$ on vegetative shoots and from 3.78 to $10.76 \mathrm{~cm}$ on generative ones. The coefficients of variation on vegetative and generative shoots ranged from low to moderate. The mean blade width (BW) varied from 4.77 to $10.04 \mathrm{~cm}$ on vegetative shoots and from 3.09 to $7.32 \mathrm{~cm}$ on generative ones. The coefficients of variation on vegetative and generative shoots ranged from low to moderate. The mean blade length/width ratio (BL/BW) varied from 1.16 to 1.58 on vegetative shoots and from 1.19 to 1.63 on generative ones. The coefficients of variation on vegetative and generative shoots was low. The mean position of the widest part of the blade as percentage of its length (PWB) varied from 31.04 to 54.34 on vegetative shoots and from 33.04 to 54.34 on generative ones. The coefficients of variation of this trait for vegetative and generative shoots ranged from low to moderate. The mean number of veins to the left of the midrib (NVL) varied from 4.2 to 7.7 for leaves on vegetative shoots and from 4.0 to 6.0 for leaves on generative ones. The coefficients of variation on vegetative and generative shoots ranged from low to moderate. The mean number of veins to the right of the midrib (NVR) varied from 4.5 to 7.8 on vegetative shoots and from 4.0 to 5.8 on generative ones. The coefficients of variation on vegetative and generative shoots ranged from low to moderate. The mean 


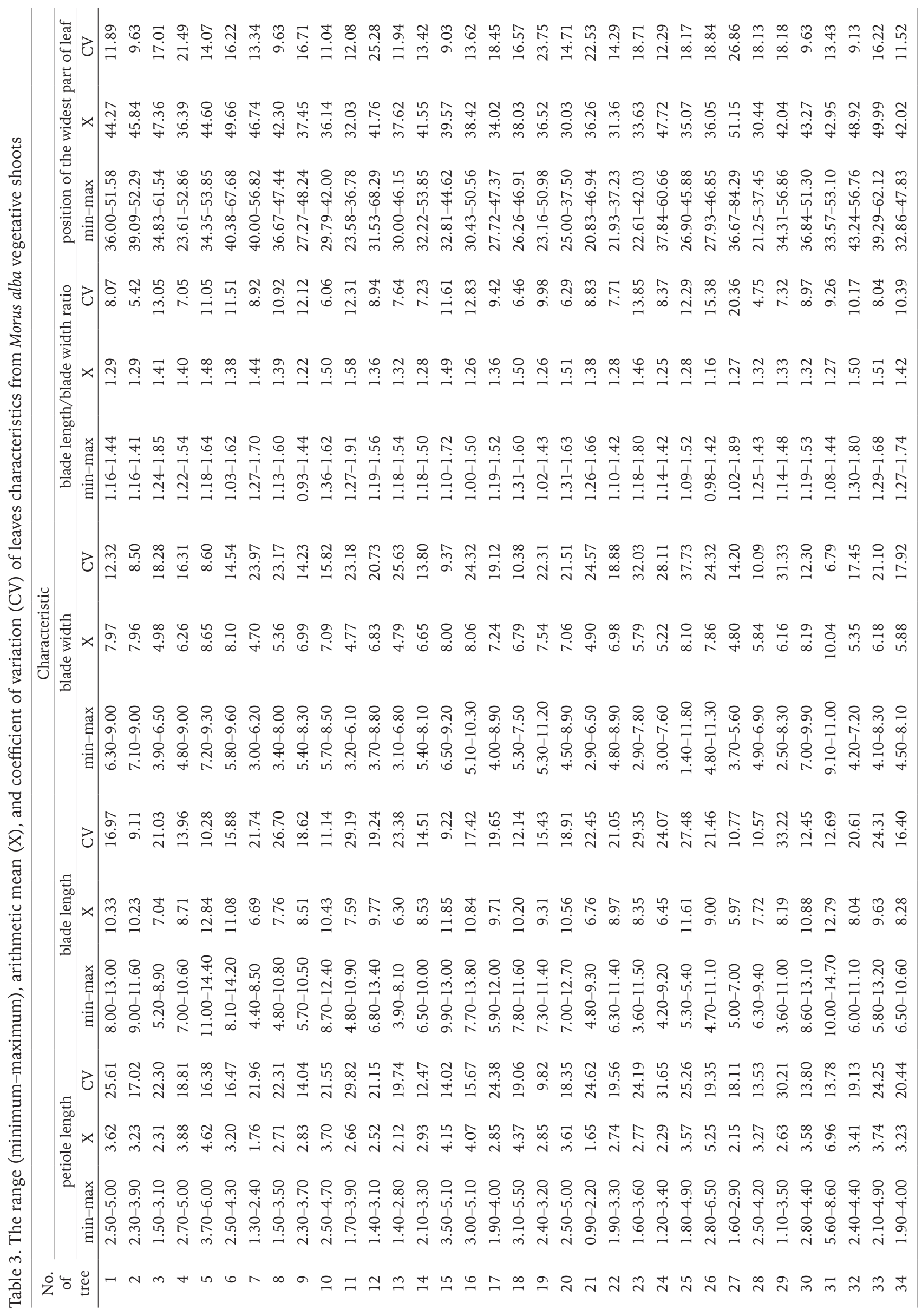




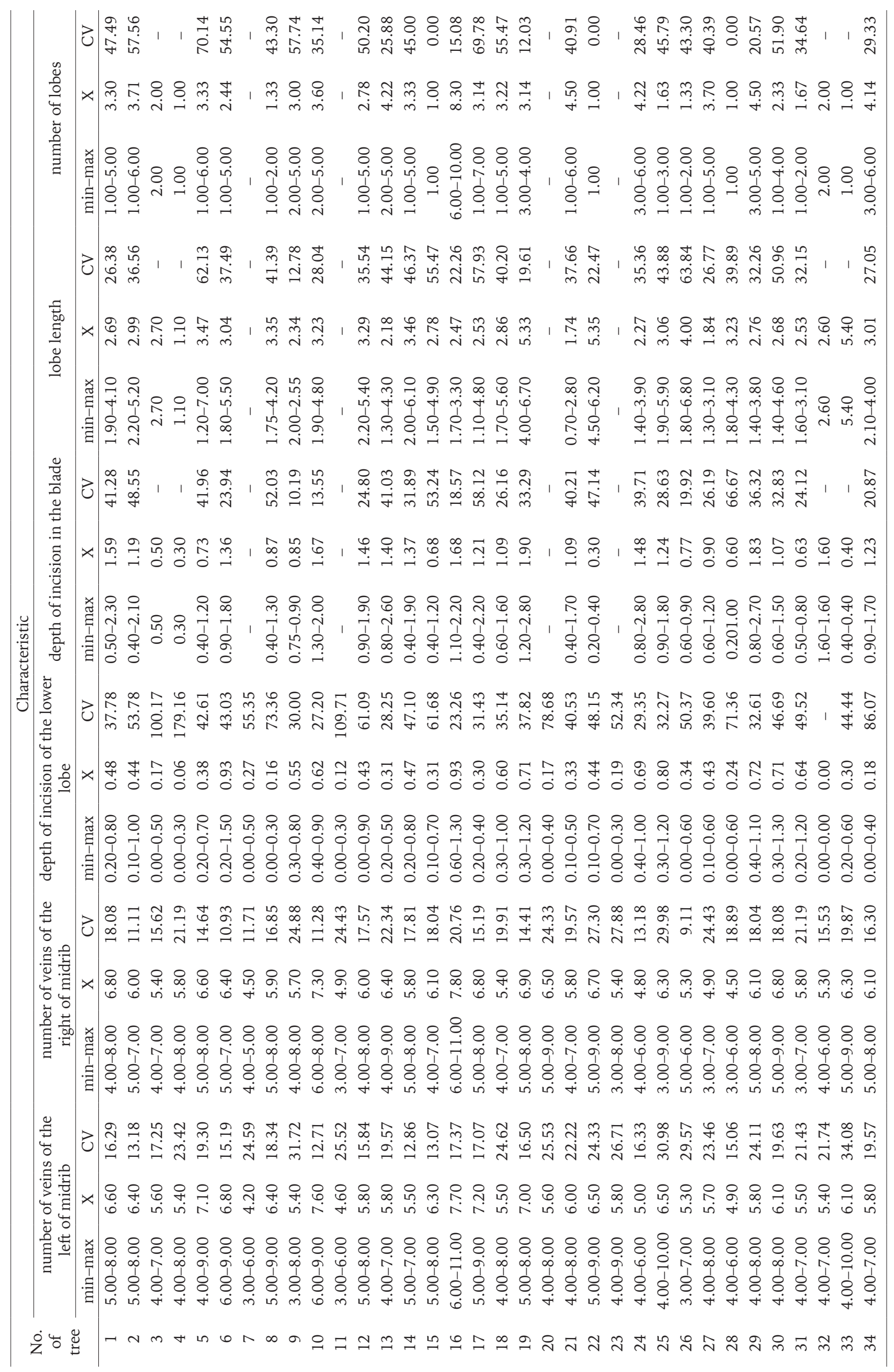




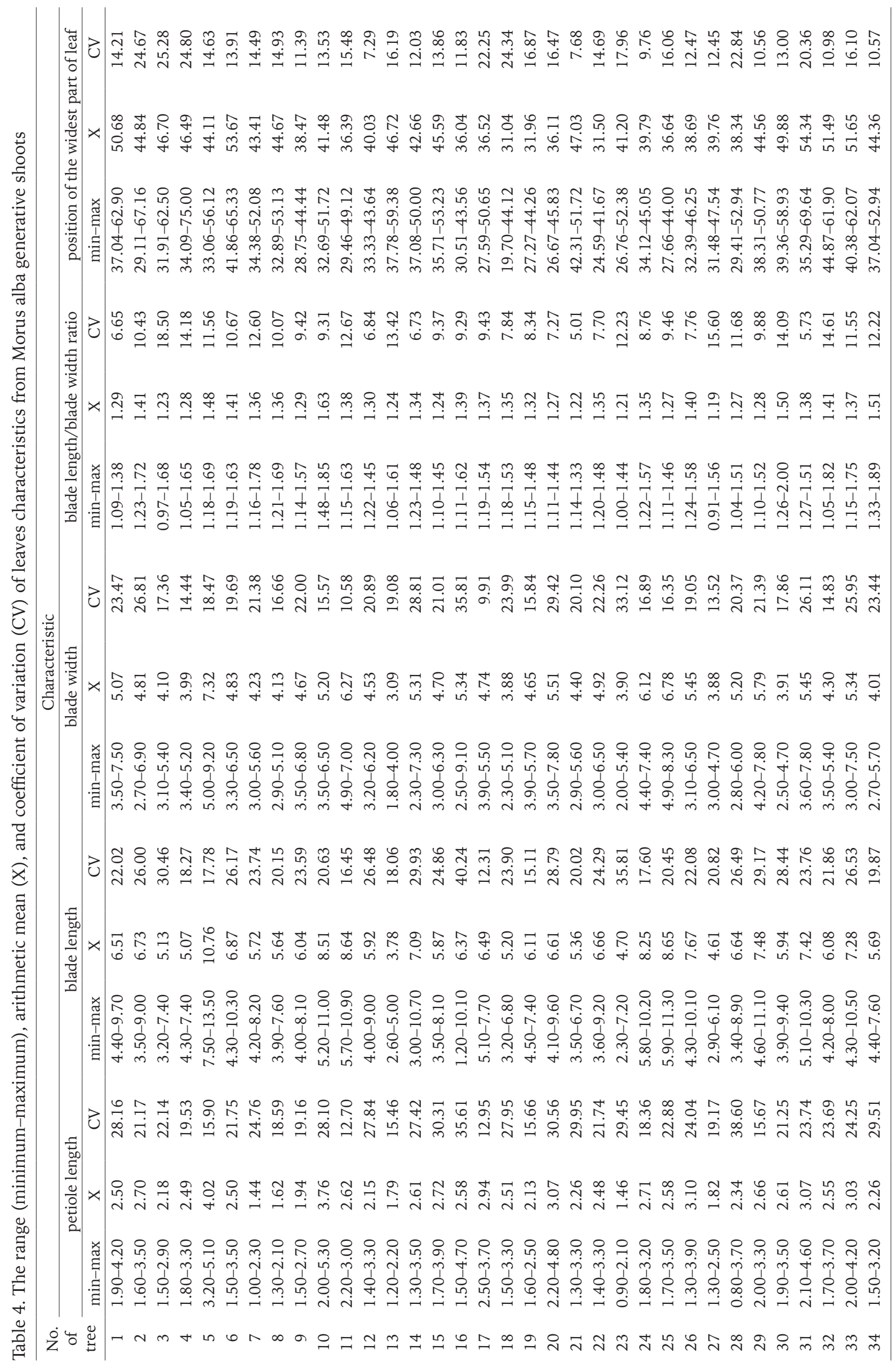



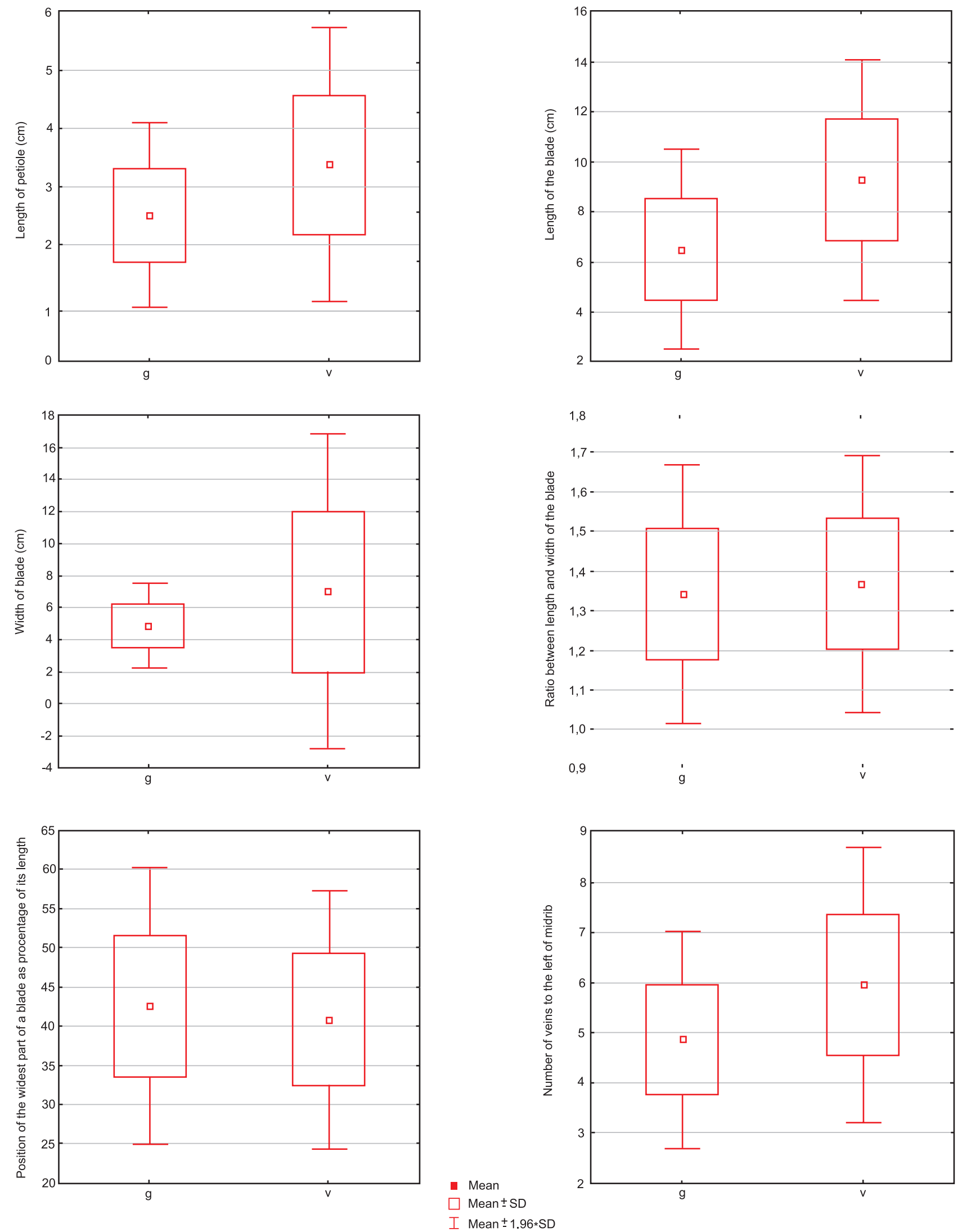

Fig. 2. Box-plot diagrams for the six characteristics of Morus alba leaves under study 

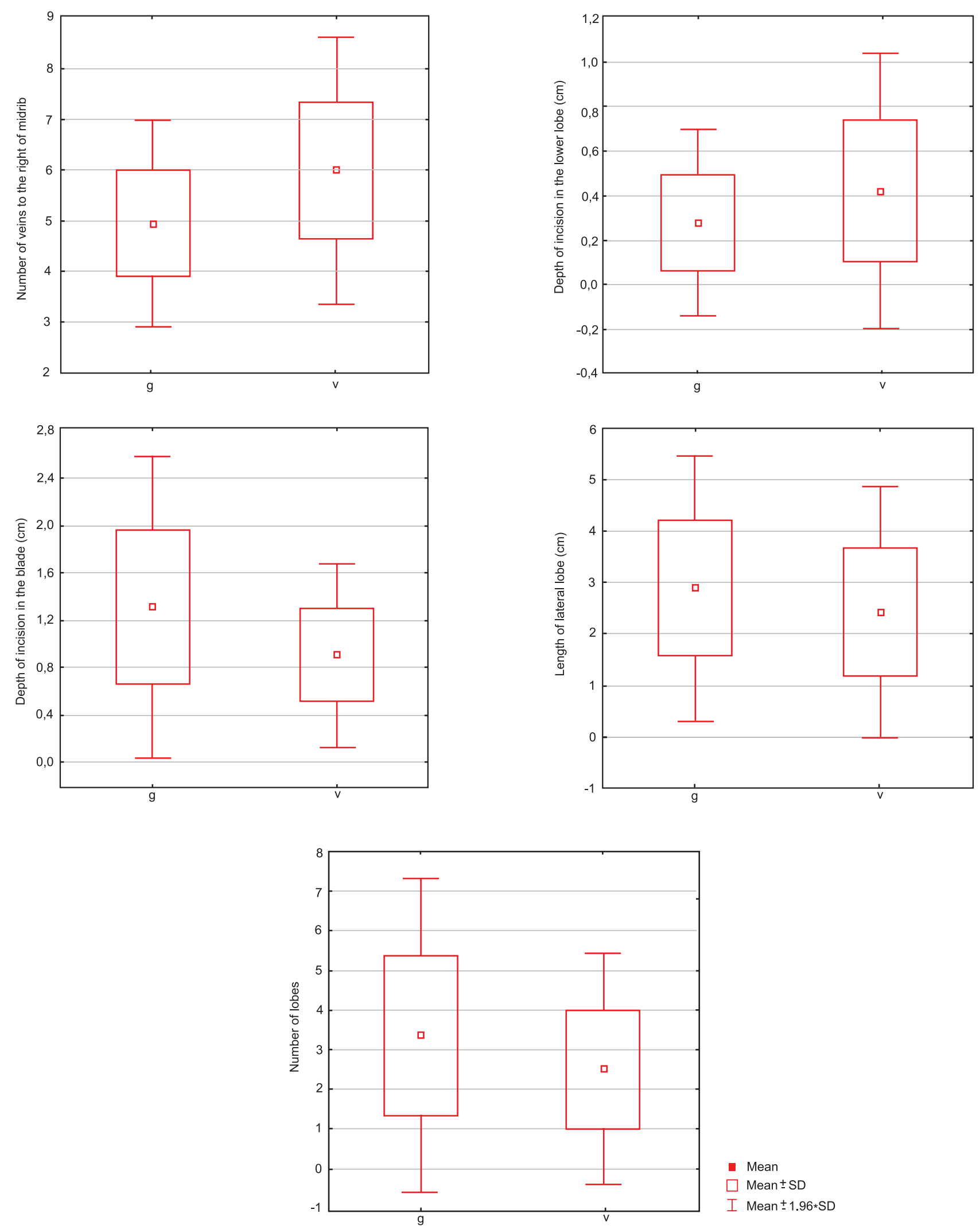

Fig. 3. Box-plot diagrams for the five characteristics of Morus alba leaves under study 
Table 5. A comparison of leaves characteristics from vegetative and generative shoots (Student's t-test for dependent samples): G - generative shoots, SD - standard deviation, $\mathrm{V}$ - vegetative shoots

\begin{tabular}{|c|c|c|c|c|c|c|c|c|c|}
\hline \multirow{2}{*}{ No. } & \multirow[b]{2}{*}{ Features } & \multicolumn{4}{|c|}{ Mean } & \multicolumn{4}{|c|}{ Student's t-test } \\
\hline & & $\mathrm{V}$ & G & SDV & SDG & no. of leaves & $\mathrm{t}$ & $\mathrm{df}$ & $\mathrm{p}$ \\
\hline 1 & PL & 3.27 & 2.51 & 1.20 & 0.81 & 1700 & 11.5187 & 339 & 0.000 \\
\hline 2 & BL & 9.14 & 6.51 & 2.44 & 2.03 & 1700 & 17.2506 & 339 & 0.000 \\
\hline 3 & BW & 6.96 & 4.88 & 5.43 & 1.34 & 1700 & 6.8976 & 339 & 0.000 \\
\hline 4 & $\mathrm{BL} / \mathrm{BW}$ & 1.37 & 1.34 & 0.17 & 0.17 & 1700 & 2.0297 & 339 & 0.043 \\
\hline 5 & PWB & 40.33 & 42.55 & 8.59 & 8.99 & 1700 & -3.8641 & 339 & 0.000 \\
\hline 6 & NVL & 5.97 & 4.86 & 1.44 & 1.10 & 1700 & 11.7621 & 339 & 0.000 \\
\hline 7 & NVR & 5.97 & 4.95 & 1.34 & 1.03 & 1700 & 12.0051 & 339 & 0.000 \\
\hline 8 & DLB & 0.42 & 0.28 & 0.31 & 0.21 & 1700 & 8.1978 & 339 & 0.000 \\
\hline 9 & DL & 1.34 & 0.88 & 0.50 & 0.37 & 120 & 4.9977 & 39 & 0.000 \\
\hline 10 & LL & 2.97 & 2.46 & 1.49 & 1.22 & 120 & 2.0072 & 39 & 0.052 \\
\hline 11 & NL & 3.60 & 2.58 & 1.98 & 1.50 & 120 & 2.5157 & 39 & 0.016 \\
\hline
\end{tabular}

depth of incision in the lower lobe (DLL) varied from 0.06 to 0.93 on vegetative shoots and from 0.0 to 0.69 on generative ones. The coefficients of variation on vegetative shoots ranged from low to very high, whereas on generative shoots they ranged from moderate to very high.

Thirty-one trees had lobed leaf blades on vegetative shoots, and 15 trees had such type of leaves on the generative shoots. The depth of incisions in the blade (DB) varied from 0.0 to $1.9 \mathrm{~cm}$ on vegetative shoots and from 0.0 to $1.53 \mathrm{~cm}$ on generative shoots. The coefficients of variation on vegetative and generative shoots ranged from low to very high (Tables 3 , 4). The lobe length (LL) varied from 0.0 to $5.4 \mathrm{~cm}$ on vegetative shoots and it ranged from 0.0 to $4.75 \mathrm{~cm}$ on generative shoots. The coefficients of variation on vegetative and generative shoots ranged from low to very high. The number of lobes on the leaves (NL) from vegetative shoots ranged from 0.0 to 8.3 whereas on generative shoots they ranged from 0.0 to 4.00 . The coefficients of variation on vegetative and generative shoots ranged from low to very high.

Student's t-test for dependent samples proved significant differences between vegetative and generative shoots in ten out of eleven traits under study (Table $5)$. The lobe length was the only trait which did not exhibit significant differences between leaves from different shoots. In leaves from vegetative shoots the correlation between the blade length and width was very strong in $46 \%$ of cases, strong - in $32 \%$ of cases, moderate - in $12 \%$ and weak in $7 \%$. There was no correlation in $3 \%$ of cases. The correlation between the blade length and petiole length was very strong in $17 \%$ of cases, strong - in $44 \%$ of cases, moderate - in $22 \%$ and weak in $12 \%$. There was no correlation in $5 \%$ of cases. In leaves from generative shoots the correlation between the blade length and width was very strong in $47 \%$ of cases, strong - in $35 \%$ of cases, moderate - in $21 \%$. There was no correlation in $6 \%$ of cases. The correlation between the blade length and petiole length was very strong in $38 \%$ of cases, strong - in $35 \%$ of cases, moderate - in $21 \%$, whereas in $6 \%$ of cases there was no correlation.

The leaves from vegetative and generative shoots did not differ significantly in the correlation strength between the blade length and width $\left(\lambda^{2}=5.13\right.$; $\mathrm{df}=$ $4 ; p=0.27)$. The leaves differed in the correlation strength between the blade length and petiole length $\left(\lambda^{2}=21.16 ; \mathrm{df}=4 ; \mathrm{p}=0.000\right)$. The correlation was stronger in leaves from generative shoots.

As can be seen in the hierarchical clustering dendrogram (Fig. 4) illustrating the diversification of leaves from vegetative shoots, the collected samples can be divided into two groups. The first group includes the leaves from trees: 4, 9-11, 13, 15-21, 22, $23,25,26,28$, the second group includes the trees $1-3,5-8,12,14,27,29-34$. Within the first group at the Euclidean distance ca. 6.5, the subgroup 1.1 $(11,20,22,23,28)$ and the subgroup $1.2(4,9,10$, $13,15-19,21,25,26)$ can be distinguished. Similarly, within the second group, we can distinguish a subgroup $2.1(3,6,7,24,27,32,33)$ and $2.2(1,2$, $5,8,12,14,29-31,34)$. The dendrogram based on the characteristics of leaves collected from generative shoots is shown in Figure 5. The samples were divided into two groups. The first group includes the leaves of trees: 9-12, 16-20, 22-28, whereas the second group consist of leaves from trees: $1-8,14,15$, $21,29-34$. Within the first group, at a distance ca. 7.5, the subgroup $1.1(18,19,22)$ and $1.2(9-12,16,17$, $20,23-28)$ are separated. Within the second group the subgroup $2.1(2-4,7,8,13-15,21,29,34)$ and the subgroup $2.2(1,6,30-33)$ can be distinguished.

The principal component analysis revealed that specimens with white and dark fruit did not make clearly separated groups. However, they were slightly diversified in $\mathrm{PC} 1$, which explains $36 \%$ of the total variation (Fig. 6). 


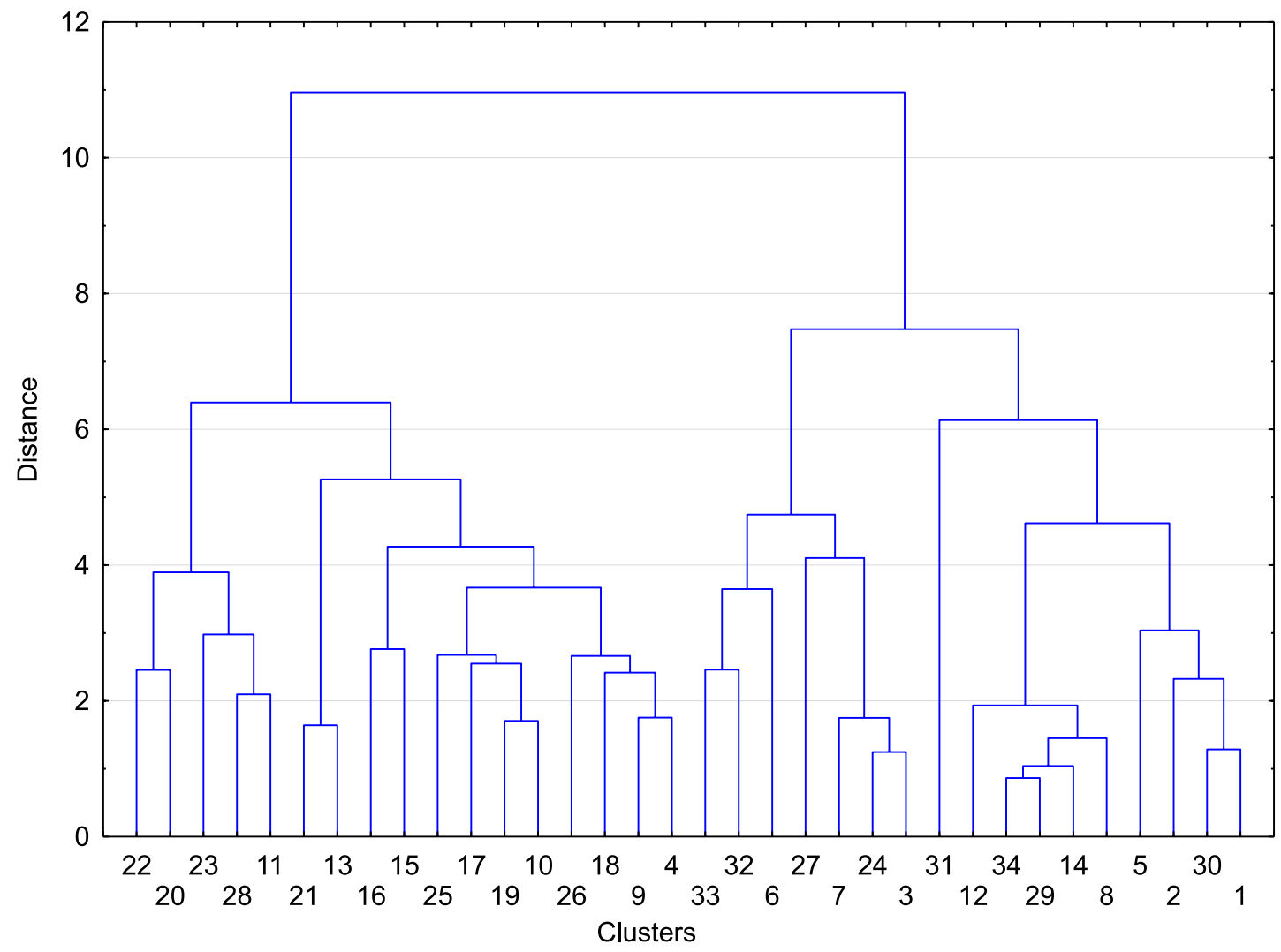

Fig. 4. Dendrogram constructed on the basis of the shortest Euclidean distances for characteristics of leaves from Morus alba vegetative shoots

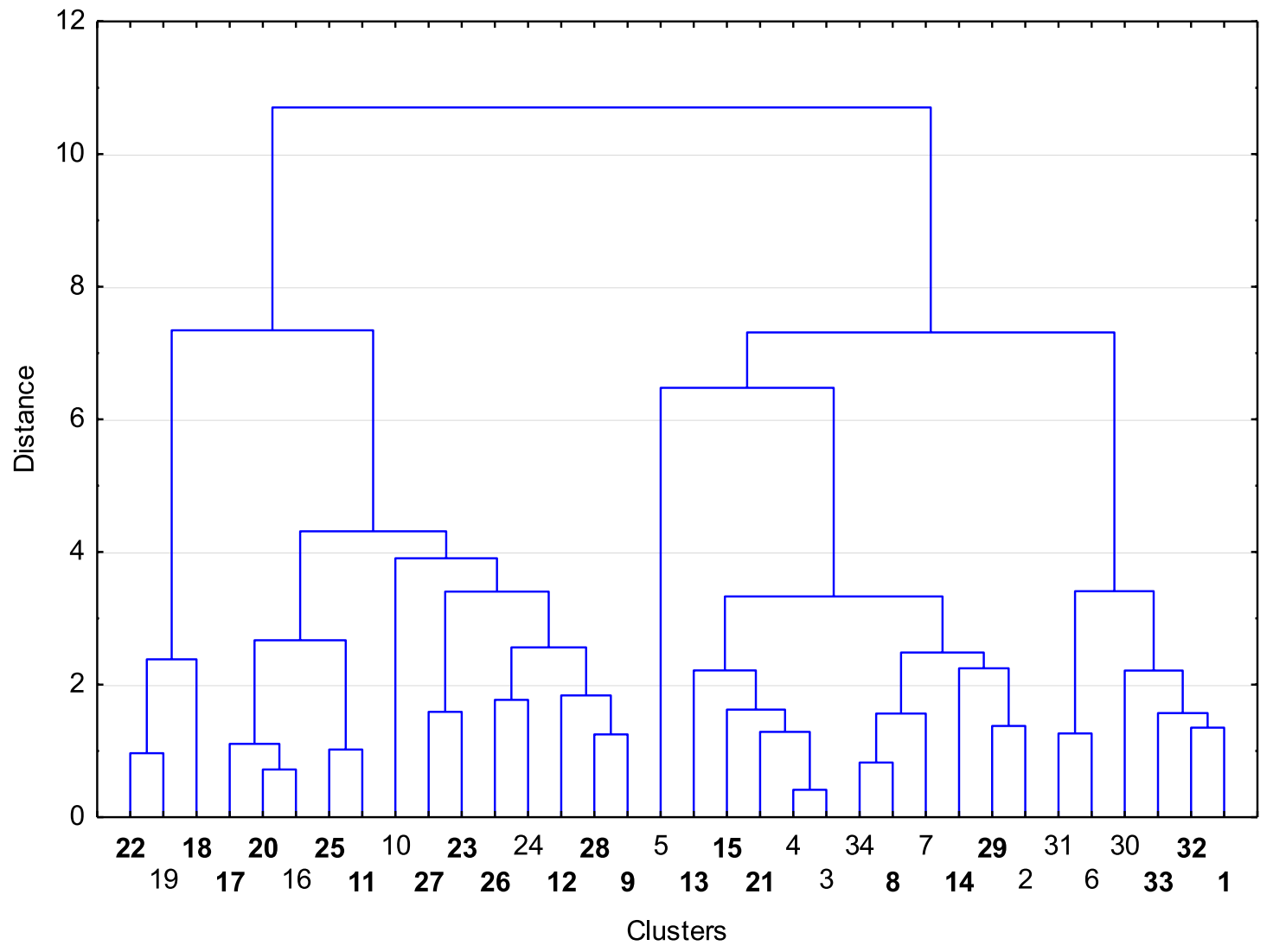

Fig. 5. Dendrogram constructed on the basis of the shortest Euclidean distances for characteristics of leaves from Morus alba generative shoots: bold - trees with white fruits 


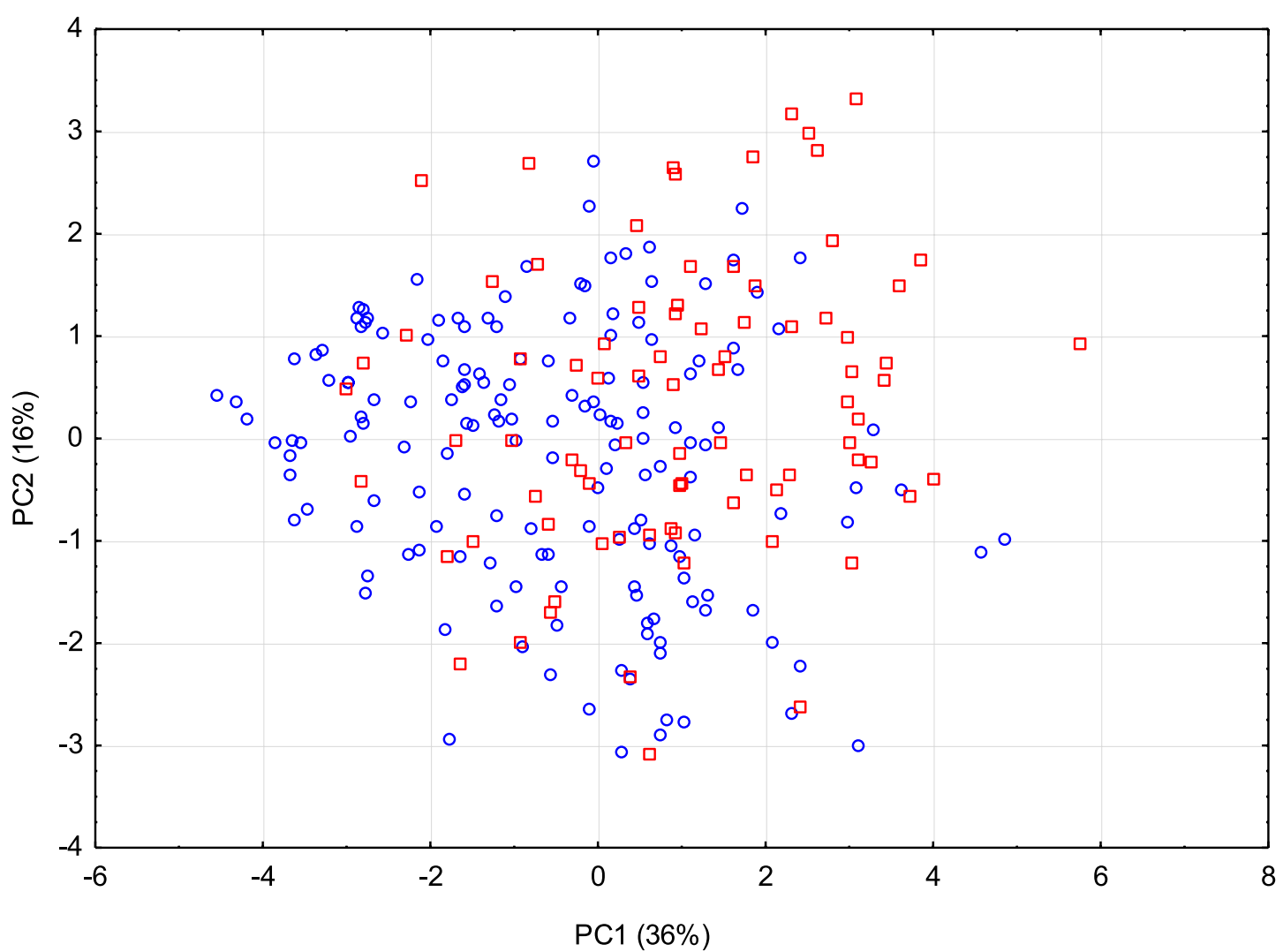

Fig. 6. The results of the principal component analysis (PCA) - scatter diagram: circle - trees with white fruit, square trees with dark fruit

\section{DISCUSSION}

In Poland, only one species of mulberry, Morus alba, is widely cultivated. Seneta \& Dolatowski (2011) inform that leaves of this species are ovate or roundish, 7-15 cm long, older trees have leaves slightly lobed or without indentations. According to Kremer (1995), the blade length varied from 7 to $18 \mathrm{~cm}$. While those examined by us on the vegetative shoots were $5.97-12.84 \times 4.7-10.04 \mathrm{~cm}$ and petiole length $1.65-6.96 \mathrm{~cm}$ and on generative shoots $3.78-10.76 \times$ $3.09-7.32 \mathrm{~cm}$ and petiole length $1.44-4.02 \mathrm{~cm}$. The seven examined features (1-7) were characterised by low or moderate variability and four features (8-11) were characterised by low or very high variability. Significant differences between vegetative and generative shoots in ten out of eleven traits was found. The lobe length was the only trait which did not exhibit significant differences between leaves from different shoots. Turskiené (2013) examined the leaves of $M$. alba trees, that have been introduced in Lithuania. They were from 6 and $10.5 \mathrm{~cm}$ long and from 5 to $8.5 \mathrm{~cm}$ wide. Petiole length ranged from 2.2 to 3.1 $\mathrm{cm}$. Moreover, TuRSKIENÉ (2013) stated that the number of veins on the right side of the blade is slightly higher than on the left side, and this observation was confirmed by our findings. ABBASI et al. (2014) collected wild plant from different areas of Lesser Himalays. The climate of this region ranges from tropical at the base of the mountans to permanent ice and snow at the highest elevation. Leaves were from 12 to $2.9 \mathrm{~cm}$ long and $12.5-1.6 \mathrm{~cm}$ wide. PerIS et al. (2014) examined the leaves from long shoots grown in Kenya. The means of the different morphological features showed that the lamina length, lamina width and petiole length were significantly differ across the two enviroments: with Eldoret they had higher parameters than Nairobi. Lamina length was $11.9 \mathrm{~cm}$ and lamina width was $9.7 \mathrm{~cm}$ from Nairobi and $17.7 \mathrm{~cm}$ lamina length and $14 \mathrm{~cm}$ lamina width from Eldoret. The mean petiole length was $2.9 \mathrm{~cm}$ and 3.6 (respectively). Blade length was positively and significantly correlated to blade width and petiole length which was confirmed by our study. Significant positive correlation was also found between lamina length and petiole length growth height. ZHeKUn \& GILBERT (2003) report, that in M. alba there are two varieties of this species: alba and multicaulis. M. alba var. alba L. is characterised by blackish purple or purple fruit and leaf blade 5-15 $\times 5-12 \mathrm{~cm}$. $M$. alba var. multicaulis (Perrottet) Loudan has dark fruit and leaf blade ca. $30 \mathrm{~cm}$ and petiole length 1.5-5.5 $\mathrm{cm}$. According to Katsumata (1971) and Kumar et al. (2012), M. alba L. and M. multicaulis Perrottet are 
separate species. The length of petioles studied by BOUBAYA et al. (2009) in M. alba ranged from 1.93 to $6.56 \mathrm{~cm}$. BAJPAI et al. (2015) studied the phenotypical variability in natural white mulberry populations (Morus alba) at high altitudes (2815-3177 m AMSL) in Himalays. Coefficient of variation showed high phenotypic variability of length, width of leaves as well as petiole length. Each 100-metre increase in the altitude caused the leaf length, width and area to decrease by $1 \mathrm{~cm}, 0.8 \mathrm{~cm}$ and $16.6 \mathrm{~cm}^{2}$, respectively. The incision in the blade is a key characteristic of $M$. alba leaves. At the base there is no incision in the leaf blade or it is much shallower than the petiole length (SZAFER et al. 1969). Our study confirmed this observation - the average depth of the incision in the blade of vegetative shoots was $1.33 \mathrm{~cm}$, whereas in generative shoots it was $0.87 \mathrm{~cm}$. The average length of petioles amounted to $3.27 \mathrm{~cm}$ and $2.51 \mathrm{~cm}$, respectively. To sum up the results of dendrograms we can say that the leaves from vegetative shoots were located in different subgroups even if they came from near sites and from generative shoots showed that the groups isolated due to their greatest similarity were not related to each other in terms of a specific colour. Comparisons of the biometrical data of morphological features of leaves with different localities showed that the ranges of trait variability overlap. The largest dimensions of mulberry leaves (11.32$21.43 \times 7.61-15.63 \mathrm{~cm}$ ) and greatest petiole length $(2.06-4.36 \mathrm{~cm})$ had the leaves from natural localities in India (BANERJE et al. 2007).

\section{CONCLUSIONS}

The analysis of the material confirmed the relation between the size and shape of leaves and the type of shoots. There were significant differences between vegetative and generative shoots. The leaves from the trees with light yellow to creamy fruit and the from the trees with dark purple to purple fruit exhibited the smallest differences in the ratio between the blade length and width. White mulberry leaves (Morus alba) with white and coloured fruit did not make clearly independent groups. Therefore, they should be treated as morphotyp of cultivars rather than given a taxonomic distinction.

\section{ACKNOWLEDGEMENTS}

We are grateful to Wojciech Klimko for his assistance with computer data recording. The authors would like to thank two anonymous reviewers for their suggestions and comments on an earlier version of the manuscript. The study was supported by the Department of Botany, the Poznan University of Life Sciences.

\section{REFERENCES}

Abbasi A.M., Khan M.A., Ahmad M., Munir M., Zafar M., Sultana S., Mishwani Z., Uliach Z. (2014): Ethnobotanical and taxonomic screening of genus Morus for wild edible fruits used by the inhabitants of Lesser Himalayas-Pakistan. Journal Medicinal Plant Research 8(25): 889-898.

Adolkar V.V., Raina S.K., Kimbu D.M. (2007): Evaluation of various mulberry Morus spp. (Moraceae) cultivars for the rearing of the bivoltine hybrid race Shaashi BV-333 of the silkworm Bomyx mori (Lepidoptera: Bombycidae). International Journal Tropical Insect Science 27: 6-14.

Bajpai P.K., Wargha A.R., Yadav A., Kant A., Srivastava R.B., Stobdan T. (2015): High phenotypic variation in Morus alba L. along an altitudinal gradient in the Indian trans-Himalaya. Journal of Mountain Science 12(2): 446-455.

Banerje R., Roychowdhuri S., San H., Das B.K., Ghosh P., Saratchandra B. (2007): Genetic diversity and interrelationship among mulberry genotypes. Journal of Genetics and Genomics 34(8): 691-697.

Boubaya A., Ben Salah M., Marzougui N., Ferchochi A. (2009): Pomological characterization of the mulberry tree (Morus spp.) in the south of Tunisia. Journal of Arid Land Studies 19(1): 157-159.

Bugaza W. (2000): Drzewa i krzewy. Państwowe Wydawnictwo Rolnicze i Leśne, Warszawa.

FAO/IAEA. (2007). Mutant germplasm characterization using molecular markers. A manual prepared by the Joint FAO/IAEA division of nuclear techniques in food and agriculture. International Atomic Energy Agency (IAEA), Vienna.

GoLAŃSKI K. (1957): Poradnik chowu jedwabników. Państwowe Wydawnictwo Rolnicze i Leśne, Warszawa: 16-24.

KATSUMATA F. (1971): Shape of idioblasts in mulberry leaves with special reference to the classification of mulberry trees. Journal Sciences Japan 40: 313-322.

KцImко M. (2016): Micromorphology and anatomy of leaves of Morus alba L. (Moraceae) cultivars from Poland. Steciana 20(2): 73-83.

KREMER B.T. (1995): Drzewa. Leksykon przyrodniczy. GeoCenter International, Warszawa.

Kumar V., Kodandaramaih J., Rajan M.V. (2012): Leaf and anatomical traits in relation to physiological characteristics in mulberry (Morus sp.) cultivars. Turkish Journal Botany 36: 683-689.

ŁUKASIEWICZ Sz. (2011): Drzewa i krzewy polecane do obsadzeń ulicznych w miastach (ze szczególnym uwzględnieniem środkowo-zachodniej Polski). In: M.E. Drozdek (ed.). Rośliny do zadań specjalnych. Wydawnictwo Państwowej Wyższej Szkoły Zawodowej, Sulechów: 313-324. 
Peris N.W., Gacheri K.M., Theophillus M.M., Lucas N. (2014): Morphological characterization of mulberry (Morus spp.) accessions grown in Kenya. Sustainable Agriculture Research 3(1): 10-17.

Poкorný J. (1992): Drzewa znane i mniej znane. Polska Oficyna Wydawnicza BGW, Warszawa.

Seneta W., Dolatowski J. (2011): Dendrologia. Wydawnictwo Naukowe PWN, Warszawa: 161-162.

Sokal R.P., Sneath P.H.A. (1973): Principles of numerical taxonomy. W.H. Freeman, San FranciscoLondon.

StASzKIEWicz J. (1997): Zmienność liści gatunków z rodzaju porzeczka - Ribes (Grossulariaceae). In: J. Staszkiewicz (ed.). Zmienność wybranych gatunków krzewów i drzew. Fragmenta Floristica et Geobotanica Series Polonica, Suppl. 2: 45-68.

Szafer W., KulczyŃski S., Pawłowski B. (1969). Rośliny polskie. Państwowe Wydawnictwo Naukowe, Warszawa.

TOKARSKa-GuZiK B., Dajdok Z., ZająC M., ZająC A., Urbisz A., Danielewicz W., HoŁdyński C. (2012):
Rośliny obcego pochodzenia w Polsce ze szczególnym uwzględnieniem gatunków inwazyjnych. Generalna Dyrekcja Ochrony Środowiska, Warszawa: 142-185.

TURSKIENÉ E. (2013): Juodojo (Morus nigra L.) ir baltojo (M. alba L.) silkmedžiu morfologinés charakteristikos. Dekoratyviuju ir sodo augalu sortimento, technologiju ir aplinkos optimizavimas. Mokslo darbai (4) 9: 165-172.

Wataza C. (2002): Biostatystyka. Alfa Medica Press, Bielsko-Biała.

ZheKun Z., Gilbert M.G. (2003): Moraceae. In: Z.Y. Wu, P.H. Raven, D.Y. Hong (eds). Flora of China 5: 21-73.

For citation: Kachel M., NowińsKa R., Klimko M. (2017): The variability of Morus alba L. (Moraceae) leaves in the green areas of Poznan. Steciana 21(1): 17-29. doi: 10.12657/steciana.021.003 